\title{
Spontaneous Order and Relational Sociology: From the Scottish Enlightenment to Human Figurations
}

\author{
Alex Law \\ PhD, Division of Sociology, Abertay University \\ Address: Bell St., Dundee, DD1 1HG, UK \\ E-mail:a.law@abertay.ac.uk
}

\begin{abstract}
If viewed from a long-term and large-scale perspective, human interdependencies today can be seen as approaching species integration on a worldwide level. However, emergent worldwide processes of integration and differentiation tend to be reduced to static conceptthings such as "governmentality", "globalization", "cosmopolitanization", "mobilities", and "networks", helping to obscure the mundane processes of institution formation, in particular the tenacious endurance of the nation-state. This paper argues that the pathological realism of neoliberal globalization today can be more adequately approached by engaging with the historical precursors of the so-called "relational turn" in contemporary sociology. The earlier relational sociology of the Scottish enlightenment, particularly Adam Ferguson (1767), Adam Smith (1776) and David Hume (1739) developed ideas of spontaneous order and such related concepts as "the invisible hand" and "unintended consequences" in an attempt to understand and control the rapid transformation of Scotland, a relatively under-developed economy on the edge of Europe. The Scottish spontaneous order tradition is compared to Elias's idea of "figuration" as an unplanned but patterned process of increasingly complex and opaque social interdependencies and functional democratization. This process appears to have reached definite limits. Humanity is ensnared in a compelling global double-bind process of armed states that continue to threaten, endanger and fear each other, and a pervasive elite belief in the spontaneous efficiency and self-correcting mechanisms of the global "magic market".

Keywords: spontaneous order, Scottish enlightenment, Norbert Elias, human figurations, national habitus, relational sociology
\end{abstract}

(C) Alex Law, 2017

(C) Centre for Fundamental Sociology, 2017

DOI: $10.17323 / 1728-192 \mathrm{X}-2017-4-14-36$ 
When one considers what a great number of sounds, forms reach us at every moment of our existence ... nothing is easier than to configure! Configure! For a split second this word took me by surprise like a wild beast in a dark forest, but it soon sank into the hurly-burly of the seven people sitting here, talking, eating, supper going on.

Witold Gombrowicz, Cosmos

From plans arising, yet unplanned

By purpose moved, yet purposeless

Norbert Elias, The Society of Individuals

\section{Introduction}

If viewed from a long-term and large-scale perspective, human interdependencies today can be seen as approaching species integration on a worldwide level. However, emergent worldwide processes of integration and differentiation tend to be reduced to static concept-things such as "governmentality", "globalization", "cosmopolitanization", "mobilities", and "networks", helping to obscure the mundane processes of institution formation, in particular the tenacious endurance of the nation-state. In response to unplanned processes, static concepts either bewail or celebrate new global threats and opportunities. Fantasy "they-images" of the dangerous outsider and inter-state rivalries are today bolstered by what the American sociologist Charles Wright Mills (1958) sixty years ago called "crackpot realism". Mills (1958: 90) was referring to the dogmatic calculus of the "power elite", political, media, economic and military managers who imposed gross simplifications on contested realities, reacting to foreshortened time horizons and shifting events which threaten to overwhelm: "The crackpot realist does not know what he will do next; he is waiting for another to make a move". Moral and political dilemmas, Mills feared, were being sacrificed to a mythical belief in "the autonomous forces of the magic market" where "the unintended consequences of many wills form a pattern and that this pattern ought to be allowed to work itself out" (Mills, 2008: 101). With Hayek's reformulation of unintended consequences, the concept was transformed from an enlightened means of orientation to foster human improvement and self-knowledge into the counterenlightenment denial that planned improvement and foreknowledge were at all possible or even desirable (Ullmann-Margalit, 1997).

This paper argues that the pathological realism of neoliberal globalization can be more adequately approached by engaging with the historical precursors of the so-called "relational turn" in contemporary sociology. It traces the genealogy of the relational sociology of spontaneous order to the Scottish enlightenment, particularly Adam Ferguson (1767), Adam Smith (1776) and David Hume (1739) (Smith, 2009), in order to situate the present concerns of relational theory with mundane social change to the rapid social and economic transformation of a peripheral society on the margins of eighteenth-century Europe, a transformation unparalleled until the Meiji restoration in Japan after 1868 and 
the gargantuan scale and breakneck pace of Stalin's forced industrialization of the USSR in the 1930s. While Adam Smith's ideas of the "invisible hand", the role of sympathy in emotional solidarity and the "impartial spectator" as a self-reflexive observer of others are well known, this paper also considers the early contribution of Smith's compatriot David Hume to nascent sociology, which, compared to his political histories and moral philosophy, is less well understood. Hume's approach to relational interdependencies fostered by "sympathy" represented what Duncan Forbes (1975: 106) called "the highwatermark of his sociological imagination". Although he did not use the term - the first use of "spontaneous order" is attributed to Michael Polanyi (1951) two hundred years later (Jacobs, 1999) - much of the spontaneous order tradition traces its roots to Adam Ferguson's proto-sociology of civil society. This contained the essential features of later relational theories in statu nascendi, albeit with significant differences, and exerted a profound influence on thinkers as different as Hegel, Marx, Durkheim, Hayek, Foucault and Elias (Hill, 2006; Petsoulas, 2001).

The founding of the spontaneous order tradition by the Scottish enlightenment groped towards what has more recently been described as "relational sociology" (Emirbayer, 1997). While relational sociology takes various forms, at its core it shares with the Scottish enlightenment a conception of interdependent social relations as a reality sui generis. As Hume (2007 [1772]: 80) expressed the common assumption underlying the earlier form of relational sociology: "The mutual dependence of men is so great in all societies that scarce any human action is entirely complete in itself, or is performed without some reference to the actions of others, which are requisite to make it answer fully the intention of the agent."

In this paper the Scottish spontaneous order tradition is compared to the more recent "relational turn" in sociology, focusing particularly on Norbert Elias's notion of "figuration" as an unplanned but patterned social process of social interdependencies and functional democratization. This allows some conclusions to be drawn about the sociology of the unintended yet anticipated consequences of pathological realism today.

\section{Nominalization and Human Figurations}

"How does it happen at all", the sociologist Norbert Elias (2012a: 404) asked, "that formations arise in the human world that no single individual has intended, and which are anything but cloud-like formations without stability or structure?" Elias found a simple enough answer in the "compelling dynamics" of human figurations as a spontaneous order. Here the "whole secret" of the figuration as a blind process consists in how "from the interweaving of countless individual interests and intentions - whether tending in the same direction or in divergent and hostile directions - something comes into being that was not planned and intended by any of these individuals yet emerged nevertheless from their intentions and actions" (Ibid.: 346-347). Elias (Ibid.: 526) compared figurations to a social dance, a structure relatively independent of specific dancers, in the sense that these dancers could be replaced by others, but never of individual dancers themselves. 
Spontaneous order forms the central paradox of figurational processes. As individuals cooperate or conflict with each other their interdependent relations create "an order sui generis, an order more compelling and stronger than the will and reason of individual people composing it" (Ibid.: 404). Asymmetrical power ratios are often conceived as formed either by the independent relations of hermetically isolated agents exercising free-will or by the dependent relations of the unilateral domination of powerless subordinates. In such cases, the individual and society appear as distinct and even antithetical to each other. By contrast, for relational sociology interdependencies always shape the possibilities for action, to varying degrees, for all sides of the relationship (Elias, 2012b: 125). Sociologists in the spontaneous order tradition therefore attempt to explain both sides of a single process: purposeful inter-personal action and unintended impersonal consequences. What Elias (2012a: 403) termed the "civilizing process" occurs over many centuries without purposive planning by individuals yet at the same time it "is not merely a sequence of unstructured and chaotic changes". It evinces a discernible pattern and direction across time.

As the chains of interdependency become longer, more dense and opaque the overall shape of the figuration becomes more difficult to discern for the people ensnared in it. A more open or latent ambivalence among people tends to characterise more opaque relations of interdependency. As Elias (Ibid.: 352) put it: "All people, all groups, estates or classes, are in some way dependent on one another; they are potential friends, allies or partners; and they are at the same time potential opponents, competitors or enemies". Feelings of affection and enmity are muted to varying degrees by the contradictory demands of complex figurations, particularly where groups attain more or less equal power chances that cancel out each other. This results in a tension-balance where no side is capable of unilaterally imposing its will on the other. More or less evenly balanced contending sides come to be regulated by a centralised authority, above all the machinery of state. Again, neither side of the inter-dependent relationship planned this outcome. It is set in train by the mutual compulsions of the entire figuration.

Earlier attempts to grasp this process remained trapped in functionalist ideals about the rational designs of the mind. One such attempt was Hegel's "cunning of reason" which proceeds by allowing "the passions" to act on behalf of "the general Idea", "the ultimate purpose of the world", which mysteriously uses the concrete particulars of actual historical agents so that historical necessity may somehow triumph whatever the intentions of the people involved (Hegel, 1975: 89). Nevertheless, Hegel was wrestling with a genuine paradox of his time. As social processes are experienced increasingly as exerting a compelling force beyond the control of people, impersonal metaphors, nouns and static categories come to be adopted as a standard mode of communication about human integration (Elias, 2012b: 86-87). The reduction of processes to static concepts makes it more difficult to understand the socio-historical momentum of spontaneous orders (Mennell, 1992).

Sociological thinking has come to be dominated by what Billig (2013: 144-161) calls "the big nouns", concept-things such as "governmentality", "globalization", "cosmopoli- 
tanization", "mobilities", and "networks". Noun phrases, terms for things, are made to do the heavy lifting for sociological explanation by subordinating or displacing verbs, terms for action. Critical discourse analysts identify "nominalization", the process of converting a clause into a nominal or a noun, as a way of deleting people and action from language (Billig, 2008). Yet the use of "nominalization", a verb turned noun, commits even critical discourse analysts to similar processes of "agent-deletion". Paradoxically, concepts of globalization, governmentality and networks and so on rely on the very forms of depersonalization that its proponents seek to unmask. As Billig (2013: 152) argues, the more that sociologists produce concepts as things, the more that the research agenda uncovers ever more examples of the concept-thing, the more that the concept-thing is taken for reality by researchers.

Nominalization is not a new problem for sociology. In the 1960s Norbert Elias (2009) sharply criticised both the "nominalist metaphysics" of Karl Popper's hypothetico-deductive logic of science and Talcott Parsons's "analytical realism". Both Mills and Elias had reason to challenge the dominant post-war sociological meta-theory of Parsons. In elaborating history-structure-biography as a single sociological process, Mills (1959: 23) famously excoriated the "Grand Theory" of Parsons for its "elaborate and arid formalism" as an unintelligible, "rather abstract and static" conceptual system. Impervious to specific empirical problems, Mills argued that Grand Theory functioned less as an explanatory model and more as an exercise in ideological legitimization for elite we-ideals of an American Cold War normative consensus. Elias (2012a: 497-501) levelled similar charges, if less polemically, that Parsons reduced diachronic processes to short-term, static and stand-alone categories of "the individual" separated from a homeostatic "social system", where social change defied empirical explication and occurred only as a "malfunction" of an otherwise normatively consensual social system. Like Mills, for Elias (Ibid.: 510) Parsons conflated empirical analyses and normative ideals in a meta-theoretical system which resembled the idealised self-image of America as a well-integrated, harmonious and democratic nation of equals.

In the case of Parsons's contemporary, Robert Merton (1936) "the unanticipated consequences of purposive social action" referred to "the sum-total or concrete consequences" for the actor and other persons mediated by the social structure, culture and civilization. Merton (1968) later designated such outcomes in terms of the functional needs required by "the social system", for instance the need for group cohesion or institutional reproduction secured through an unintended "latent function" as well as its foreseen or "manifest function" in the reproduction of a social system. In so doing, Merton conflated the "unintended" aggregate effects of a myriad of informal individual actions and the "unanticipated" effects of formal institutional action as more self-conscious forms of decision-making.

From such premises, unintended consequences increasingly came to be identified with or used as a synonym for unanticipated consequences. Yet, unintended perverse effects can be either foreseen or unforeseen (Boudon, 1982). As de Zwart (2015: 286) notes, "unanticipated consequences can only be unintended, but unintended consequences can 
be either anticipated or unanticipated, a distinction lost in the single opposition of 'intended' versus 'unintended"' This conflation serves politicians, managers, policy-makers, and analysts who take considerable measures to ascertain the likely outcomes of their purposive actions, and so are not "unanticipated", to evade responsibility for their actions. Undesirable outcomes - say military violence, economic crisis or widening inequalities - are excused on the basis that they were unforeseen. Yet, while the deleterious consequences may have been an unintended side-effect of some other priority they were nonetheless eminently foreseeable.

Anthony Giddens (1984) developed a trenchant critique of Merton's "functionalist" turn and with the theory of structuration provided a more sophisticated account of unintended consequences which dispensed with Merton's mystificatory "functional needs". Instead, Giddens outlined how unintended consequences form the "unacknowledged" ground of further action as both the enabling medium and the constraining condition of the social system. While Giddens reintroduced agency and processes into the idea of unintended consequences it is less clear that structuration as a meta-theoretical system successfully circumvented the problem of nominalization at the core of the agency-structure and individual-society dualisms.

More recently, the so-called "relational turn" in sociology has attempted to overcome the structure-agency and individual-society dualisms (Dépelteau, Powell, 2013; Emirbayer, 1997). Bourdieu's version of relational sociology, for instance, occupies something approaching near-hegemonic status for much contemporary sociology. Relational sociologists reject the idea that sociological analysis begins with substantial, pre-given entities such as the individual, class, minority, state, nation or society (Emirbayer, 1997: 287). Yet, there are a wide range of approaches to, and varying emphases within, the relational turn, ranging from neo-structuralism, interactionism, constructivism, phenomenological, pragmatism and critical realism (Crossley, 2011; Dépelteau, Powell, 2013; Donati, Archer, 2015). Often, however, one side of the dualism is still assumed to predominate over the other; sociological relations emerge either from situated exchanges between individuals or as a property of the wider structuring force of the social system (Law, 2015). In attempting to overcome the "substantialist" fallacy in sociology which treats cultural practices as thing-like essences, even Bourdieu's (1998) claim that "the real is relational" remains limited to analysing relations between vacant, thing-like "positions" or "properties" of the social field that come to be occupied according to "position-taking" choices made possible by the sociogenetic dispositions of habitus.

Of the classical sociologists, Georg Simmel (2009 [1908]) placed the greatest stress on social relations, and even minted an active term, "sociation", to distinguish his relational sociology from passive and substantialist approaches to "society". Individuals for Simmel (1997 [1911]: 120) are "bearers of the processes of association" who pursue specific interests through innumerable relationships, "with-one-another, for-one-another, in-one-another, against-one-another, and through-one-another, in state and commune, in church and economic associations, in family and clubs". In part deriving his methodological relationism from Simmel, what Elias (2012b) called "figurations" similarly af- 
forded primacy to interdependent social relations as a single process as the proper object of relational sociology.

\section{Democratization Processes and Human Survival Units}

Much of the relational turn shares a penchant for meta-theoretical nominalization of pregiven categories. For Elias, on the other hand, it is sociologically more useful to examine specific, socially compelling processes such as changes through time in the personality structure and the state formation process. As societies become more complex, differentiated and integrated, social change can be explained less and less in terms of the intentions, will or rationality of individuals and groups. As the differentiation of social functions proceeds so does the differentiation of the human personality, which becomes more sensitised, self-conscious and habitual under the compulsion of multiple dependencies on countless others. Sociogenesis and psychogenesis emerge together in unplanned ways that only later may become subject to more self-conscious controls and more adequate means of human orientation. Popular culture, music, art and fashion, for instance, operate in a tension balance between spontaneity and self-consciousness in a typically cyclical pattern of relatively unselfconscious spontaneity followed by the increasingly selfconscious controls and calculations of commodification and standardisation processes (Elias, 2017).

When viewed through the lens of long-term curves of development, short-run, contingent events are not simply random occurrences but exhibit a shape, a pattern and a sequence of flow. History evinces two main directions for Elias, tending over many generations, either towards greater or lesser social integration and differentiation, thus rejecting the false choice between the Scylla of static structures and the Charybdis of unpatterned contingencies (Elias, 2012a: 6). More complex, differentiated and integrated figurations emerge out of less complex, differentiated and integrated ones. However, while an earlier figurational flow is a necessary precondition for a later one to emerge, the later figuration is not the inevitable or necessary outcome of the earlier one, which may or may not develop in a range of different possible ways (Elias, 2012b: 157). Worldwide violent conflagrations such as the First and Second World Wars may appear as shortlived bursts of destruction, bending away from the longer-term development curve of self-restrained regimes of emotional regulation, but they nevertheless depend upon the necessary, though not inevitable, preconditions of protracted but unplanned state formation processes (Wouters, 2016).

Figurations find their limit and inner coherence only in dialectical relation to other, external figurations. At the core of this process is the need for humans to create institutions for struggles of self-defence and attack, what Elias (2012a) called "survival units". Historically survival units have taken different forms, families, tribes, villages, city-states and so on. Today the preeminent survival unit is the state form constituted and defined by its relationship with other states. Compelled by mutual contact and fear of rival states an unplanned "double-bind" process of reciprocal surveillance, adjustment and armed 
preparation is set in train. In the light of Elias's defensive figurations, Kaspersen and Gabriel (2013: 77) rule out the possibility for the emergence of a single, global survival unit encompassing the whole of humanity on the basis that it will have no other unit outside of itself against which it is compelled to struggle and survive. A global state cannot function as a survival unit. Instead, Kaspersen and Gabriel (2013) appeal to von Clausewitz's principle that defensive survival units are more tensile and resistant to the concentrated military force of offensive units and impose a precarious "pause" on asymmetrical warring states who are compelled to mutually recognise the sovereignty of each other. In contrast, during the Cold War Elias (2010) entertained the, admittedly remote, possibility of global governance exerting a monopolization of the means of violence capable of inducing a worldwide pacification process through difficult struggles of human learning to collectively avoid catastrophic wars, including nuclear war (Landini, Dépelteau, 2017).

Shifting asymmetrical power ratios are a function of lengthening chains of human interdependencies. The transition from dynastic elites monopolising power chances to the progressive narrowing of the power differentials between the governed and governments demonstrates the deepening processes of what Elias called "functional democratization" involving more and more interdependent people. By deploying the term "functional democratization" Elias (2012a: 63) refused to limit the process of more equal power chances arising from functional specialization to "institutional democratization", arguing that the process of social equalization was as evident in one-party states as it was in multi-party states. Power differentials have reduced between many groups, classes, races, men and women, heterosexuals and LGBTI, and so on. For example, the unequal power imbalances of parent-child relations have narrowed considerably. They are strikingly less marked by punitive authority relations and are increasingly characterised by more egalitarian relations of parental self-restraint and greater child autonomy alongside advancing adult thresholds of shame and embarrassment (Elias, 2008). Hume (1969 [1739-1740]: 538) made a similar observation about a more even power balance between parents and children with the quickening of the civilising process in mid-eighteenth century Scotland: "Parents govern by the advantage of their superior strength and wisdom, and at the same time are restrain'd in the exercise of their authority by that natural affection, which they bear their children."

This process cannot be understood either voluntaristically as the result of conscious planning or, as Hume assumes, naturalistically as an innately universal feeling. Instead, Elias (2008: 32 ) argues that it results from a compelling dialectical process of intentional and unintentional changes in the mutual constraints that interdependent people and non-human nature exercise on each other, with "the interweaving of the planned acts of many people results in a development of the social units they form with each other, unplanned by any of the people who brought them about".

Nor is functional democratization simply conceived as a unilinear process of increasing social harmony, integration and consensus. It is always beset by many tensions and reversals. Development towards a less uneven distribution of power chances, Elias (2012a: 64) argued, "permeates the whole gamut of social bonds, although there are impulses 
simultaneously running counter to this trend". Stephen Mennell (2014:12) termed such counter-trends "functional de-democratization" and recently argued that the balance of socio-economic inequality and power resources for both America and at a global level has tipped "back in favour of the more privileged, and global interdependences are increasingly interwoven with countries' internal power ratios". None of this bodes well for the possibility of the global monopoly of violence that Elias hoped would mitigate the dangers of armed inter-state power rivalries.

\section{Spontaneous Order in the Scottish Enlightenment}

Elias' approach to figurations as unplanned but purposeful demonstrates a clear indebtedness to the human science of unintended consequences developed by the leading figures of the Scottish enlightenment (Hill, 2006). Elias appears to have assimilated the spontaneous order tradition of the Scottish enlightenment as mediated by Hegel, Marx and Williams Sumner (van Krieken, 1998: 23). Just as Elias reacted against the prevailing philosophical and sociological perspectives of his time, so also Adam Ferguson, David Hume, Thomas Reid, Adam Smith, William Robertson, Lord Kames, John Millar and Gilbert Stuart reacted strongly to the mythical thinking of social contract theory which attributed a wholly imaginary origin for society and the state in pre-social individuals combining to secure their own survival and offering their tacit consent to be ruled by a governing institution. As Hume (1969 [1739-1740]: 600) argued, no one can give their consent without first of all having some knowledge of the promise made in their name. Similarly, and despite some shared moderate Calvinist convictions, they also rejected the "Great Legislator" theory, which posited an imaginary origin for social institutions created by the free will and intentions of a mythical force or individual such as God or a king. The unintended effect of incremental changes may escape the purview of the people exposed to it. For instance, the emergence of civil society was not the result of the purposive rationality of great legislators. "But though this progress of human affairs may appear certain and inevitable, and though the support which allegiance brings to justice be founded on obvious principles of human nature, it cannot be expected that men should beforehand be able to discover them, or foresee their operation" (Hume, 1993 [1776]: 30). Hume therefore considered it necessary to understand the historical momentum of social and political processes rather than isolate sudden disruptive lurches that he associated with violent episodes contingent on the passions of a few people.

By developing a distinctive sociological perspective Hume attempted to argue on the realist basis of what he considered demonstrable or at least indisputable facts about the nature of humans in society. He founded his social science on the principle that what depends on a small number of people is largely a matter of "chance" while what arises from larger numbers may be assigned "determinate and known causes" (Hume, 1993 [1776]: 57). As John Millar (2006 [1803]: 730) described the relational process underpinning all human survival units: 
The first aim of every people is to procure subsistence; their next is to defend and secure their acquisitions. Men who live in the same society, or who have any intercourse with one another, are often linked together by the ties of sympathy and affection; as, on the other hand, they are apt, from opposite interests and passions, to dispute and quarrel, and to commit mutual injuries. From these different situations, they become sensible of the duties they owe to each other, and of the rights which belong to them in their various relations and capacities.

Similarly, Ferguson began from the "universal characteristics" of shared human dispositions. These include the ability to reason through foresight and reflection, judgement, knowledge, disciplined habits, and interests. A natural but unplanned propensity for language, for instance, makes the beneficial diffusion of knowledge possible, indeed makes society itself possible.

Like Elias, the Scottish enlightenment groped towards a long-term process theory and rejected as futile the endless search for the origins of collective institutions. Adam Smith (1963 [1762-1763]: 88) urged that an infinite regress of causal origins should be avoided by pursuing historical inquiry only to the point that "we know all that is necessary of the matter". Here Smith's emphasis on sufficient historical knowledge appears to contrast with the impossibility of acquiring the knowledge necessary for establishing the multiple preconditions of the spontaneous order coordinated by the famous "invisible hand". An individual, Smith (1976 [1776]: 456) argued, "neither intends to promote the public interest, nor knows how much he is promoting it". Individual intentions are limited by concerns for personal security and personal gain. In this, Smith (1976 [1776]: 456) famously claimed that an individual is "led by an invisible hand to promote an end which was no part of his intention". By sacrificing knowledge of public benefits to the immediate gratifications of self-interest Smith's invisible hand often serves as a model for the mythical neoliberal idea of the "magic market" as a self-regulating mechanism. Yet Smith (1963 [1762-1763]: 85) also argued that immediate events are always the result of remote causes, themselves subject to even remoter ones. Smith's historical approach was primarily concerned with how social action contributed towards revolutionary change in states and governments. "Design and contrivance" not "accident and chance" therefore must form the proper object of historical study as a means of human orientation.

Ferguson (1980 [1767]: 144) tended to share Smith's invisible hand principle that "private interest is a better patron of commerce and plenty, than the refinements of state" (Ferguson, 1980 [1767]: 144). As Lisa Hill (2006: 105) argues, for Ferguson, like Millar, the accumulation of wealth derives from an instinctive need for subsistence, generating a causal chain of unintended effects that "inadvertently leads to technical improvements in production; the development of private property leads to the emergence of legal and political establishments; the herding instinct develops, over time, into nationalistic sentiments and thereafter leads to the emergence of sovereign states." It is not only individuals that progress over the course of their lifetime but the species itself builds on the accumulated history of socially-acquired knowledge. Each generation, Ferguson (1980 [1767]: 5) claimed, "builds in every subsequent age on foundations formerly laid; and, in a succes- 
sion of years, tend to a perfection in the application of their faculties, to which the aid of long experience is required, and to which many generations must have combined their endeavours."

Hill (2006: 121) compares Ferguson's process theory to the operation of deep structures, hidden mechanisms or innate essences that lie behind surface phenomena in structuralist theory. However, where structuralism tends to posit stasis, function and system Ferguson posited change, conflict and progress. Humans were believed to be possessed of an innate drive for improvement, "the desire of something better than is possessed at present" as Ferguson (1792: 207) put it. Among human desires, Ferguson listed the need for more wealth and property, more effective government to promote "the peace and good order of society", more scientific knowledge, more refined arts, and more adequate philosophical theories.

However, self-interest in wealth-maximization cannot provide the limit of human dispositions. Other "disinterested" passions - hate, indignation, and rage - may be opposed to and undermine self-interested profit. Neither does economic self-interest necessarily result in public benefit. As Ferguson (1980 [1767]: 12), two centuries before Karl Polanyi (2001 [1944]) and Mills (1958), noted, narrow self-interest comes to dominate and erode other more fundamental human dispositions, "the principles of self-preservation", which provide the ground from which self-interest initially arose and which will produce ruin and violence unless restrained by the rule of civil society. Ferguson adopted a teleological view of the evolution of institutions. Short-term "efficient causes" at the level of individual instincts, drives, habits, frailties, pleasure and pain contribute blindly to longterm "final causes" at the level of entire human survival systems. Ferguson's providentialist view of spontaneous order conceived of humans as too feeble to grasp God's cosmic design let alone attempt to realise it. Restless human activity is guided by the unknown movements of a hidden God: "The scenes of human affairs change in his management: his emblem is a passing stream, not a stagnating pool" (1980 [1767]: 7).

In effect, Ferguson, Smith, Hume and their compatriots attempted to empirically establish general patterns of social life, not isolated, individual deviations, through historical and comparative analysis. Like Elias, Ferguson wanted to subordinate any appeal to benevolent normative outcomes of unplanned social processes to a more adequate description of reality, desirable or otherwise (Bogner, 1986). Where empirical evidence was obscure or missing altogether from the historical record, a universal theory of human nature or "theoretical history" would supply the basis for making reasoned "conjectures", sociological judgements and comparative knowledge of human relations. Given universal human propensities and broadly similar historical condition then similar institutions governments, religion, arts, science - were also assumed likely to emerge.

\section{Public Benefits and Private Vices}

Bernard Mandeville's Fable of the Bees was an important precursor for the Scottish spontaneous order tradition (Goldsmith, 1988). Mandeville (1970 [1714-1723]) famously made 
the "public benefits" of wealth and power counter-intuitively dependent on "private vices", such as greed, theft, envy, vanity, pride, domination and ambition. Vice, not virtue, creates social complexity through the demand for recognition, goods and services. For instance, the need of anonymous strangers for social approval in large modern cities creates a culture of vanity in the wearing of fashionable clothing for "the pleasure of being esteemed by a vast majority, not as what they are, but what they appear to be" (Mandeville, 1970 [1714-1723]: 152). From Mandeville's perspective, no wealthy and powerful nation could at the same time be a nation of moderation and virtue.

By such means Mandeville opened the way for Scottish intellectuals to consider the tensions and conflicts of ordinary human sociability without resorting to the moralist valuations of elites. Hume reserved particular invective for Shaftesbury's (1999 [1711]) detached refinement of polite manners. He rejected the inflated but fashionable pretensions of polite moralists like Shaftesbury who "exalt our species to the skies, and represent man as some kind of demigod" (Hume, 1993 [1776]: 43). For Hume, while the private interests of individuals are multiple and varied, the public interest is always the same. In response to the dispute over Mandeville's intended vice/unintended benefits duality, Hume (Ibid.: 47) argued that if self-love and vanity really did predominate in human affairs over sociable and virtuous principles then human nature would indeed be "contemptible". Hume (Ibid.: 177) also rejected Mandeville's idea that the vice of self-interest was generally beneficial to society as "little less than a contradiction in terms". Hume's trans-valuation of values (1969 [1739-1740]: 349) proactively reversed the usual relationship between virtue and vice: "by pride I understand that agreeable impression, which arises in the mind, when the view either of our virtue, beauty, riches or power makes us satisfy'd with ourselves: and by humility I mean the opposite impression". Virtue, not vice, excites pride, while vice, not virtue, produces humility. Emotional affects are derived from the "double relation" of self and perception. Both virtue and vice are related to the same object, the self, but relate differently to what Hume called "the impressions", that is, whether the perception of the cause of the passion is pleasurable (pride) or painful (humility or shame).

Pride and humility are not fixed as eternal sources of vice and virtue as Mandeville and orthodox moral philosophy assumed. In fact, Hume claimed, private vice cannot be so precisely demarcated from the ascribed virtues of public benefit. Self-interest is not the acme of social relations. Instead private egos are always embedded in and moderated by a dynamic process of sociability rendered by a human capacity for sympathy and pleasure in emulation, imagined or real. Individuals take self-satisfaction from mind, body and external objects (Ibid.: 330-331). Pleasure is taken by the self-regarding individual, first, by "imagination, judgment, memory or disposition; wit, good-sense, learning, courage, justice, integrity"; second, in the exercise of bodily powers, "beauty, strength, agility, good mien, address in dancing, riding, fencing, and of his dexterity in any manual business or manufacture"; and, finally, in the relationship of the self to external objects, especially the personal possessions elevated by "commercial society": "Our country, family, children, relations, riches, houses, gardens, horses, dogs, clothes". A "secondary cause" of pride arises from the reputation that the self acquires through the sentiments of others, 
particularly individuals and groups that we ourselves approve of: "Our reputation, our character, our name are considerations of vast weight and importance; and even the other causes of pride; virtue, beauty and riches; have little influence, when not seconded by the opinion and sentiments of others" (Ibid.: $366-367$ ). This, in turn, is sustained by the security and protection provided by detached and rational public institutions of government, law and economy.

Wealth and power provided Hume (Ibid.: 362) with what he considered "one of the strongest arguments" needed "to prove the influence of the double relations of pride and humility". Under conditions of increased self-restraint power and money are augmented by an imagined anticipated pleasure in their use and a vicarious comparison with less powerful and subordinate others. Hume acknowledged that luxury may become a vice where it consumes the personal wealth of individuals and prevents at least part of it from being put to other, more virtuous uses such as education or poor relief. It is therefore necessary, Hume argued, to trade off opposing vices, say to prefer vicious luxury over public idleness, on the basis of which would be the least damaging to the public interest.

Hume (Ibid.: 647) conceded that visible signs of self-satisfaction and vanity mutually excite "the greatest indignation in each other". It is difficult for individuals to be confident that feelings of self-regard are merited and well-founded in the eyes of others. Pride therefore varies, from a vicious and unmerited "overweening conceit" to a justified good opinion of ourselves, while pride in others is often judged harshly by our own offended pride. To assert otherwise, as Mandeville did, rested on two fallacies. First, the supposed vice of taking "secret pleasure" from virtuous acts of altruism or friendship gets the relationship the wrong way around: self-love derives from virtue not virtue from self-love. Second, any vanity that comes from public recognition is almost inseparable from virtue itself: "To love the glory of virtuous deeds is a sure proof of the love of virtue" (Hume, 1993 [1776]: 49).

Pride must be concealed by "some disguise", maintaining a "fair outside, and have the appearance of modesty and mutual deference in all our conduct and behaviour" (Hume, 1969 [1739-1740]: 648). Ostentatious displays of pride are placed under restraint by the social conventions of good manners embedded in the personal and social habitus. Generally accepted social conventions dictate the precise balance to be struck between pride and humility across the different classes of society. "Tis necessary therefore to know our rank and station in the world, whether it be fix'd by our birth, fortune, employments, talents or reputation. 'Tis necessary to feel the sentiment and passion of pride in conformity to it, and to regulate our actions accordingly" (Ibid.: 649).

Hume was dealing with an earlier phase of the democratization process when it seemed "natural" in "common life and conversation" to afford different classes of people unequal modes of recognition. Subordinates were presumed by Hume (Ibid.: 410-411) to spontaneously sympathise with their social superiors, even when no personal advantage could be expected, due to the "the secondary satisfaction" of reflected glory in the wealth and power of others: 
A man, who is himself of a competent fortune, upon coming into a company of strangers, naturally treats them with different degrees of respect and deference, as he is inform'd of their different fortunes and conditions; tho' 'tis impossible he can ever propose, and perhaps wou'd not accept of any advantage from them. A traveller is always admitted into company, and meets with civility, in proportion as his train and equipage speak him a man of great or moderate fortune. In short, the different ranks of men are, in a great measure, regulated by riches, and that with regard to superiors as well as inferiors, strangers as well as acquaintances.

Just as laws are established to secure property in commercial society against competing interests so rules of "good-breeding" and decency are established "to prevent the opposition of men's pride, and render conversation agreeable and inoffensive". "Mutual deference or civility" emerges from "the arts of conversation" of well-mannered interlocutors "regulated by riches" and "good breeding".

\section{Habitus and State Formation Processes}

Once an improvement in the economy of manners is collectively adopted its continued practice transforms it into part of the habitual dispositions of self, what Elias and Bourdieu called "habitus". As a disposition acquired by repeated actions, habitus refers not only to what individuals chose to do but also to what they feel inclined or compelled to do. In line with Ferguson's Protestant ethic, a habitus acquired by persevering in the overcoming of difficulties is to be commended while a habitus borne of idleness is to be condemned. Any learned habit must engender "some serious passion" if it is to surmount difficulties and not become "insipid or frivolous" (Ferguson, 1792: 229). Exposure to repeated dangers and difficulties temper the passions. As habit takes hold, emotional passions lose their force without lapsing into indifference. "The veteran becomes cool and deliberate in the midst of occasions that try his temper; he becomes at the same time far from indifferent, but resolute and able in the conduct of affairs to which he has been long accustomed: He has an easy recourse to the expedients in practice, or to the considerations in persuasion and argument, on which he has decided the part which he acts" (Ibid.: 229-230).

An innate capacity for judgement enables humans to adapt habits through the "power of discerning" and to overcome embodied limitations as "the artificer of [their] own nature" (Ibid.: 227). Habits imposed under external constraint by an external body may at first be resisted as painful but with repeated exposure over time come to be experienced as a personal power that provides satisfaction and pleasure. What was initially repugnant in manners, fashion, housing, or diet may become pleasing and desirable. What was once awkward and forced for the personal habitus becomes familiar and automatic.

Social institutions like government come to be embedded over time in piecemeal fashion through the accretion of habit, convention and custom as public authority and private individuals become increasingly interdependent: "as private men receive greater security, in the possession of their trade and riches, from the power of the public, so 
the public becomes powerful in proportion to the opulence and extensive commerce of private men" (Hume, 1993 [1776]: 156). Improved, more realistic knowledge and more restrained inter-personal relations result: "When the tempers of men are softened as well as their knowledge improved, this humanity appears still more conspicuous, as is the chief characteristic which distinguishes a civilized age from times of barbarity and ignorance" (Ibid.: 171). Power is circumscribed by ever more complex interdependencies where "very considerable motives lie betwixt him and the satisfaction of his desires, and determine him to forebear what he wishes to perform" (Hume, 1969 [1739-1740]: 363). Thus, when a hypothetical enemy of an unarmed Hume passed by on the street armed with a sword, he nevertheless felt secure: "I know that the fear of the civil magistrate is as strong a restraint as any of iron, and that I am in as perfect safety as if he were chain'd or imprison'". Without such external constraint, however, Hume's enemy may feel no such restraint and acquire "a full power" over him "as his subject or vassal". Only social learning from past experience of the conventions of the world provides people with the security and confidence that violence is unlikely, or, where violence is possible and perhaps even probable, that the uncertainty and contingency of the situation is routinely experienced as painful and reactive.

Mutual restraint from arbitrary violence emerged under what Hume (1993 [1776]: 59) described as "a free government". The earliest form of rule Hume called "barbarous monarchy" where authority was centred in the person of a despotic prince and the exercise of power was discretionary and unrestrained at all levels. Such lawless tutelage debases people and makes life precarious. Under such insecure conditions neither art nor science are able to develop. Hume next considered republican government as placing definite checks on unlimited authority to protect free citizens and secure property relations. Republics depend on a chain of interdependencies where the "candidates for office must look downwards to gain the suffrages of the people" (Ibid.: 68). Inter-personal security acts as a stimulus for knowledge and civility: "From law arises security; from security curiosity; and from curiosity knowledge" (Ibid.: 62).

In the case of republics "where power rises upwards", the relative independence of citizens enables greater scope for emulation in useful knowledge and industry but offers less possibility for polite refinement and deference. In Hume's final case, "civilised monarchy", the chains of interdependency are arranged more minutely and political candidates "must turn their attention upwards, to court the good graces and favour of the great". While the people depend on the sovereign for security, the prince feels so detached from their private intrigues and interests that the loose chain of inter-dependencies barely registers in his remote calculations. In the case of civilised monarchies, "there is a long train of dependence from the prince to the peasant" that neither threatens property relations nor hinders the ingenuity of the people, who seek to emulate the dominant models of polite manners "most acceptable to people of condition and education" (Ibid.: 69).

Political authority based on collective allegiance emerges over time as an imperfect, pragmatic process to curtail and regulate civil disorder and violence. It is conditional on 
the public interest in security and protection. Human exigencies create institutions to meet an immediate need to restrain violence and facilitate security (Ferguson, 1792: 206).

Men cannot live without society, and cannot be associated without government. Government makes a distinction of property, and establishes the different ranks of men. This produces industry, traffic, manufactures, law-suits, war, leagues, alliances, voyages, travels, cities, fleets, ports, and all those other actions and objects, which cause such a diversity, and at the same time maintain such a uniformity in human life. (Hume, 1969 [1739-1740]: 450)

Government authority depends on routine habits of thought among the governed, habits which can be rapidly dislodged by irregular state force or draconian policies. Any use of violent force to impose opinions on the public, Ferguson (1792: 219) argued, is counterproductive, "preposterous and ineffectual". It excites militant resistance and rebellion compared to a more emollient and gradual reform of public opinion.

Only in exceptional conditions where the public interest is violently subjugated by oppressive and tyrannical government does passive obedience become what Hume called "an absurdity" and resistance justified. Otherwise both "prudence and morals" demand submission to government authority:

Submit quietly to the government, which we find establish'd in the country where we happen to live, without enquiring too curiously into its origin and first establishment. Few governments will bear being examin'd so rigorously. How many kingdoms are there at present in the world, and how many more do we find in history, whose governors have no better foundation for their authority than that of present possession? (Hume, 1969 [1739-1740]: 609)

Ferguson disputed such arguments from "refined" politicians and philosophers that demanded passive obedience from "the vulgar" and represented "every dispute of a free people" as a form of mutinous disorder. In response, Ferguson (1980 [1767]: 221) advanced a democratic critique of elite superiority: "Men of superior genius sometimes seem to imagine, that the vulgar have no title to act, or to think". Like Ferguson, John Millar also drew different conclusions from Hume concerning the "long train of dependence". Millar (2006 [1803]: 724) detected a general process of functional democratization arising from commercial "improvements" that enabled people to "more easily to gain a livelihood by the exercise of their talents, without being subject to the caprice, or caring for the displeasure of others; that is, to render the lower classes of the people less dependent upon their superiors". As relations between "the ranks" of society became more interdependent so the gradations of social distance between them also narrow, which "leaving no chasm from the top to the bottom of the scale, will occasion a continual approximation of the different ranks, and will frequently enable the inferior orders to press upon the superior. 'The toe of the peasant comes so near the heel of the courtier, that it galls his kibe' [Shakespeare, Hamlet, 5.1]" (Millar, 2006 [1803]: 725). In other words, the we-ideal of outsider 
groups was beginning to demand and expect more democratic modes of social recognition from elite groups. Established groups began to keenly feel the social proximity and intimacy of former outsider groups pressing into their backs, a precondition for the social integration and horizontal solidarity that makes modern nations possible.

\section{National Habitus}

Despite often being accused of a fixed belief in the uniformity of human nature, Hume resisted the enlightenment prejudice that universal reason would result in a cosmopolitan or Eurocentric culture. While the fine-grained interdependencies of small-scale states helped stimulate mutual communication and learning, and checked arbitrary power and authority, they also proved resistant to the hegemonic cultural and scientific pretensions of similar-sized neighbouring states (Hume, 1993 [1776]: 64). Rival nations, Hume claimed, always examine works of art from other states "with the greatest care and accuracy" and scrupulously judge them against the standards established by their own prevailing prejudices. Hume put this down to "mutual jealousy" and national competition for cultural esteem and eminence.

Trivial, everyday customs in such ways disclose differences and similarities of the national habitus. The longer that the national habitus endures then the more difficult it is to challenge or revise prevailing opinion and mores. Ferguson (1792: 217-218) drew three lessons from this unplanned process. First, individuals simply accept long-held notions unless fundamentally challenged by counter-evidence. Second, other nations are just as likely to be sincerely committed to their own unexamined habits and prejudices. Third, received opinion is often based on a stable and regular commitment to a perceived truth confirmed by habit and so not easily dislodged by novel ideas. In such ways, habit binds nations together and helps compensate for the anomic pain of isolation from the rest of humanity.

National differences are apparent in the respective tension balances at different stages in the democratization processes (Elias, 2006). A youthful Hume distinguished between the "real politeness" of the French and the "expressions of politeness" of the English. By "real politeness", Hume (1932 [1734]: 20) meant a moderate temperament, sincere kindness and a readiness to serve. By "expressions of politeness" he meant "outward deferences \& ceremonies, which custom has invented, to supply the defect of real politeness or kindness, that is unavoidable towards strangers \& indifferent persons even in men of the dispositions of the world". English manners, Hume claimed, depended on the pleasures and satisfactions of outward appearances and an imperceptibly refined charismatic performance rather than any deeper sense of inner authenticity. French manners, by contrast, depended on more deeply embedded dispositions of politeness, "tho' troublesome \& impertinent, yet serve to polish the ordinary kind of people \& prevent rudeness \& brutality", among whom Hume (Ibid.: 21) mentions washerwomen, porters and coachmen, presumably occupations of a coarser nature in England. 
Hume (Ibid.: 21) gave as an example of national differences the varying use of formal modes of address. In England, the phrase "humble servant" was dropped as soon as less formal relations were established, while in France the phrase was further adorned as "the Honour of serving", to the extent that Hume's laundress expressed her "honour" of serving him, while even social superiors spoke of their "honour" of serving their subordinates. While Hume's observations can be reduced to fixed categories of "natural" (real inner politeness) versus "artificial" practices (external expression of politeness), a more useful sociological approach is to treat them as general tendencies of the democratization process, leaning in pre-revolutionary France more heavily towards the more formal codes of court society and in Hanoverian Britain to the more informal exchanges of commercial society.

\section{Conclusion}

In the period immediately before the self-regulating global market became an established social fact an increasingly acquisitive "commercial society" in Scotland provided the relational foundations for bourgeois public authority, sociability and personal security (Finlay, 2007; Berry, 2013). Commercial society propelled the civilising process by increasing social interdependencies as part of an unplanned process. A shared sociological realism was common across the Scottish enlightenment, including by lesser luminaries such as the historian Gilbert Stuart (1778: 51): "It is from no pre-conceived plan, but from circumstances which exist in real life and affairs, that legislators and politicians acquire an ascendency among men. It was the actual condition of their times, not projects suggested by philosophy and speculation."

In commercial society industry, knowledge, and humanity reciprocally expanded together, linked by what Hume (1993 [1776]: 170-171) called "an indissoluble chain", while public authority - "laws, order, police, discipline" - became less severe and more humane compared to previous historical regimes. Millar (2006 [1803]: 773) similarly described increased external constraints and self-restraint in terms of an inter-related process of humanist normative codes and the interdependent functions of commercial society: "Mankind are induced to abstain from injustice by the feelings of humanity, which dispose them to avoid hurting their neighbours, as well as by the consideration that such a conduct will be highly conducive to their own interest; and both of these principles operate with peculiar force from the circumstances in which a commercial people is placed." Particular emphasis was placed on processes of human differentiation and integration, not least by delineating the unintended consequences of the division of labour, most notably by Smith and Ferguson. Driven by human creativity to ease arduous labour, the technical division of labour specializes tasks by a gradual, largely unplanned process of trial and error that culminated in a wholly unforeseen social division of labour. The corrosive side of commercial society identified by Ferguson in particular was later reformulated by Karl Marx in his analysis of the restless, crisis-prone nature of capitalism. 
Both the Scottish enlightenment and Elias attempted to understand "the indissoluble chain" of human integration and differentiation, without lapsing into the illusory static thinking of nominalization or the fatalism of pathological realism in their attempts to provide a more secure means of human orientation to resist the "main drift" of unplanned, self-destructive processes. Higher levels of global integration are ensnared in an unplanned tension balance of unequal power chances between states as units of national integration and survival. This does not refer simply to the demiurge of sub-rational micro-processes but more pointedly refers to the tension-balances within global interdependencies presupposed by the global "magic market" and a world system of rival states unregulated by any single, central authority (Linklater, 2016). Increased knowledge of largely unplanned, relatively autonomous processes allows for the possibility of greater human control over, and coordination of, individuals and social structures. Yet, the state formation process is part of a long run, inter-generational unintended consequence of social division, competition and conflict. Formal governance was seen by the Scottish enlightenment as necessary to meliorate the informal excesses and tensions of civil society, putting it on a more secure and peaceable footing. This process appears to have reached definite limits. World humanity is ensnared in a compelling global double-bind process of armed states that continue to threaten, endanger and fear each other.

What remains is the pathological realism that Mills (1958: 90-91) identified sixty years ago when "men equally expert in practical next steps" substituted the "unknown fear, the anxiety without end" for the reductive calculations of "known catastrophe", above all an unwinnable nuclear war. While Mills' designation of crackpot realism is subject to a rather vague idea of "the main drift" of events and a highly cohesive ruling elite dominating a fragmented mass of people, it is nonetheless suggestive of current anxieties about the catastrophic drift of global events and the "magic market" apparently beyond the control of self-contradictory political and economic elites (Davies, 2017). It also expresses Karl Polanyi's (2001 [1944]) idea of the spontaneous order as a "double movement" where the market becomes magically disembedded from its social moorings as a self-regulating machine followed by attempts to protect society from its destructive effects. Pathological outcomes are not necessarily the result of error, ignorance or stupidity in the more restrictive sense of unintended consequences but, given that such harms are often anticipated by elite planners, managers and politicians, why, de Zwart (2015: 295) asks, "do they chose to go ahead anyway". It is precisely this problem of specific figurations that requires substantive sociological analysis today.

\section{References}

Berry C. J. (2013) The Idea of Commercial Society in the Scottish Enlightenment, Edinburgh: Edinburgh University Press.

Billig M. (2008) The Language of Critical Discourse Analysis: The Case of Nominalisation. Discourse \& Society, vol. 19, no 6, pp. 783-80o. 
Billig M. (2013) Learn to Write Badly: How to Succeed in the Social Sciences, Cambridge: Cambridge University Press.

Bogner A. (1986) The Structure of Social Processes: A Commentary on the Sociology of Norbert Elias. Sociology, vol. 20, no 3, pp. 387-411.

Boudon R. (1982) The Unintended Consequences of Social Action, London: Macmillan

Bourdieu P. (1998) Practical Reason: On the Theory of Action, Cambridge: Polity Press.

Crossley N. (2011) Towards Relational Sociology, London: Routledge.

Davies W. (2017) The Limits of Neoliberalism: Authority, Sovereignty and the Logic of Competition, London: SAGE.

de Zwart F. (2015) Unintended but not unanticipated. Theory and Society, vol. 44, no 3, pp. 283-297.

Dépelteau F., Powell C. (eds.) (2013) Applying Relational Sociology: Relations, Networks, and Society, London: Palgrave Macmillan.

Donati P., Archer M. S. (2015) The Relational Subject, Cambridge: Cambridge University Press.

Elias N. (2008) The Civilising of Parents. Essays II: On Civilising Processes, State Formation and National Identity (eds. R. Kilminster, S. Mennell), Dublin: UCD Press, pp. 230-55.

Elias N. (2009) On the Creed of a Nominalist: Observations on Popper's The Logic of Scientific Discovery. Essays I: On the Sociology of Knowledge and the Sciences (eds. R. Kilminster, S. Mennell), Dublin: UCD Press, pp. 161-90.

Elias N. (2010) The Society of Individual, Dublin: UCD Press.

Elias N. (2012a) On the Process of Civilisation: Sociogenetic and Psychogenetic Investigations, Dublin: UCD Press.

Elias N. (2012b) What is Sociology?, Dublin: UCD Press.

Elias N. (2017) Spontaneity and Self-consciousness. Excitement Processes: Norbert Elias's Unpublished Works on Sports, Leisure, Body, Culture (eds. J. Haut, P. Dolan, D. Reicher, R. S. Garcia), Wiesbaden: Springer.

Emirbayer M. (1997) Manifesto for a Relational Sociology. American Journal of Sociology, vol. 103, no 2, pp. 281-317.

Ferguson A. (1792) Principles of Moral and Political Science: Being Chiefly a Retrospect of Lectures Delivered in the College of Edinburgh, Vol. 1, London: A. Strachan and T. Cadell.

Ferguson A. (1980 [1767]) An Essay on the History of Civil Society, New Brunswick: Transaction.

Finlay C. J. (2007) Hume's Social Philosophy: Human Nature and Commercial Sociability in A Treatise of Human Nature, London: Continuum.

Forbes D. (1975) Hume's Philosophical Politics, Cambridge: Cambridge University Press.

Giddens A. (1984) The Constitution of Society: Outline of the Theory of Structuration, Cambridge: Polity Press. 
Goldsmith M. M. (1988) Regulating Anew the Moral and Political Sentiments of Mankind: Bernard Mandeville and the Scottish Enlightenment. Journal of the History of Ideas, vol. 49, no 4, pp. 587-606.

Hegel G. W. F. (1975) Lectures on the Philosophy of World History: Introduction, Cambridge: Cambridge University Press.

Hill L. (2006) The Passionate Society: The Social, Political and Moral Thought of Adam Ferguson, Dordrecht: Springer.

Hume D. (1932 [1734]) The Letters of David Hume, Vol. 1: 1727-1765, Oxford: Oxford University Press.

Hume D. (1969 [1739-1740]) A Treatise of Human Nature, London: Penguin.

Hume D. (1993 [1776]) Selected Essays, Oxford: Oxford University Press.

Hume D. (2007 [1772]) An Enquiry Concerning Human Understanding and Other Essays, Cambridge: Cambridge University Press.

Jacobs S. (1999) Michael Polanyi's Theory of Spontaneous Order. Review of Austrian Economics, vol. 11, no 1-2, pp. 111-127.

Kaspersen B., Gabriel N. (2013) Survival Units as the Point of Departure for a Relational Sociology. Applying Relational Sociology: Relations, Networks, and Society (eds. F. Dépelteau, C. Powell), London: Palgrave Macmillan.

Landini T. S., Dépelteau F. (eds.) (2017) Norbert Elias and Violence, New York: Palgrave Macmillan.

Law A. (2015) Social Theory for Today: Making Sense of Social Worlds, London: SAGE.

Linklater A. (2016) Violence and Civilization in the Western States-Systems, Cambridge: Cambridge University Press.

Mandeville B. (1970 [1714-1723]) The Fable of the Bees, London: Penguin.

Mennell S. (1992) Momentum and History. Culture in History: Production, Consumption and Values in Historical Perspective (eds, J. Melling, J. Barry), Exeter: Exeter University Press, pp. 28-46.

Mennell S. (2014) What Economists Forgot (and What Wall Street and the City Never Learned): A Sociological Perspective on the Crisis in Economics. History of the Human Sciences, vol. 27, no 3, pp. 20-37.

Merton R. K. (1936) The Unanticipated Consequences of Purposive Social Action. American Sociological Review, vol. 1, no 6, pp. 894-904.

Merton R. K. (1968) Social Theory and Social Structure, New York: Free Press.

Millar J. (2006 [1803]) An Historical View of the English Government: From the Settlement of the Saxons in Britain to the Revolution in 1688, Indianapolis: Liberty Fund.

Mills C. W. (1958) The Causes of World War Three, New York: Simon \& Schuster.

Mills C. W. (1959) The Sociological Imagination, Oxford: Oxford University Press.

Mills C. W. (2008) The Politics of Truth: Selected Writings, Oxford: Oxford University Press.

Petsoulas C. (2001) Hayek's Liberalism and its Origins: His Idea of Spontaneous Order and the Scottish Enlightenment, London: Routledge.

Polanyi K. (2001 [1944]) The Great Transformation, Boston: Beacon. 
Polanyi M. (1951) The Logic of Liberty, London: Routledge \& Kegan Paul.

Shaftesbury, Third Earl of (1999 [1711]) Characteristics of Men, Manners, Opinions, Times, Cambridge: Cambridge University Press.

Simmel G. (1997 [1911]) Sociology of the Senses. Simmel on Culture (eds. D. Frisby, M. Featherstone), London: SAGE.

Simmel G. (2009 [1908]) Sociology: Inquiries into the Construction of Social Forms, Leiden: Brill.

Smith (1976 [1776]) An Inquiry into the Nature and Causes of the Wealth of Nations, Oxford: Clarendon Press.

Smith A. (1963 [1762-1763]) Lectures on Rhetoric and Belles Lettres, Edinburgh: Thomas Nelson.

Smith C. (2009) The Scottish Enlightenment, Unintended Consequences and the Science of Man. Journal of Scottish Philosophy, vol. 7, no 1, pp. 9-28.

Stuart G. (1778) A View of Society in Europe in its Progress from Rudeness to Refinement, Edinburgh: John Bell.

Ullmann-Margalit E. (1997) The Invisible Hand and the Cunning of Reason. Social Research, vol. 64, no 2, pp. 181-198.

van Krieken R. (1998) Norbert Elias, London: Routledge.

Wouters C. (2016) Functional Democratisation and Disintegration as Side-Effects of Differentiation and Integration Processes. Human Figurations, vol. 5, no 2. Available at: http://hdl.handle.net/2027/spo.11217607.0005.208 (accessed 5 December 2017).

\title{
Спонтанный порядок и реляционная социология: от Шотландского Просвещения к человеческим фигурациям
}

\author{
Алекс Ло \\ $\mathrm{PhD}$, департамент социологии, Абертейский университет \\ Адрес: Bell St., Dundee, DD1 1 HG, UK \\ E-mail:a.law@abertay.ac.uk
}

В долгосрочной перспективе и на макроуровне взаимозависимость людей распространяется сегодня на весь мир. Однако всемирные эмерджентные процессы интеграции и дифференциации принято сводить к таким статичным понятиям как «правительность», «глобализация», «космополитизм», «мобильности» и «сети», что не позволяет увидеть обыденные процессы, поддерживающие институты, в частности, национальное государство. В этой статье утверждается, что патологический реализм неолиберальной идеологии сегодня можно лучше понять, если обратиться к историческим предшественникам так называемого «реляционного поворота» в современной социологии. Более ранняя реляционная социология Шотландского Просвещения, представленная Адамом Фергюсоном (1767), Адамом Смитом (1776) и Дэвидом Юмом (1739), развивает идеи спонтанного порядка, оперируя такими понятиями, как «невидимая рука» и «непреднамеренные последствия». 
Это происходит в Шотландии, экономически малоразвитой периферии Европы, вступившей в эпоху резких изменений. Шотландские традиции осмысления спонтанного порядка сравниваются с концепцией фигураций Норберта Элиаса. Последний понимал фигурации как незапланированные, но упорядоченные процессы все более сложных и менее ясных социальных взаимозависимостей и функциональной демократизации. Эти процессы, как кажется, достигли определенных пределов. Человечество попало в ловушку непреодолимого противоречия между глобальным развитием наращивающих военную мощь и угрожающих друг другу государств и широко распространенной верой элит в спонтанную эффективность и самонастраивающиеся механизмы глобального «волшебного рынка».

Ключевые слова: спонтанный порядок, Шотландское Просвещение, Норберт Элиас, человеческие фигурации, национальный габитус, реляционная социология 